\title{
MIA2 Gene
}

National Cancer Institute

\section{Source}

National Cancer Institute. MIA2 Gene. NCI Thesaurus. Code C155865.

This gene is involved in intracellular lipoprotein transport. 